\title{
PENERBITAN MAJALAH AGAMA SEBELUM PERANG DUNIA KEDUA: ANTARA TANGGUNGJAWAB SOSIAL DENGAN PERNIAGAAN
}

\author{
Hamedi Mohd Adnan
}

\begin{abstract}
Religious magazines have played a very important role in the history of Malay magazines. Twenty percent of 120 magazines published before the Second World War can be categorised in this category. Other type of magazines were literary, Christianity, general interests, organizationals type magazines, and nationalism type of magazines. Matters concerning Islam was closely related to Malay readership. A lot of regular Malay readers were students and teachers of traditional Islamic education systems in pondok schools. Religious magazines in the period before the Second World War can be categorised into three types. They were magazines published respectively by Islamic schools, by Malay social associations, and by private publishers. However, most magazines were published as part of a social responsibility. As such, due to the lack of commercial value, most of them had short life spans.
\end{abstract}

\section{Pengenalan}

Persoalan tentang keagamaan merupakan antara tema utama yang menjadi tumpuan dalam penerbitan majalah Melayu. Sejak munculnya majalah Melayu yang pertama pada 1904 sehingga kini (2010), persoalan agama tidak pernah terkeluar dalam dunia permajalahan Melayu. Dalam tempoh masa itu, lebih 200 buah majalah yang memfokuskan persoalan agama Islam telah diterbitkan. ${ }^{1}$ Jumlah ini belum termasuk majalah umum lain yang turut menyelitkan unsur keagamaan dalam majalah masing-masing. Hampir kesemua majalah umum yang jumlahnya melebihi 350 buah pada abad ke-20 menyiarkan ruangan yang berkait agama dalam kandungan masing-masing.

Justeru agama merupakan salah satu resipi yang kerap digunakan untuk menarik perhatian pembaca. Hal ini lebih-lebih lagi dalam majalah Melayu peringkat awal. Roff ${ }^{2}$ dan Muhammad ${ }^{3}$ menyatakan bahawa agama merupakan persoalan yang amat penting. Hal ini berlanjutan dari permulaan abad ke-20 sehinggalah secepat-cepatnya pada dekad 30-an apabila "banjir besar" majalah hiburan mula melanda pembacaan 
Melayu. ${ }^{4}$ Pada peringkat awal, para pelajar Melayu di Mesir turut memainkan peranan dalam menerbitkan majalah dengan terbitnya Seruan Azhar dan Pilehan Timur. ${ }^{5}$ Bagaimanapun Hamedi menyatakan bahawa penerbitan majalah agama pada umumnya tidaklah menguntungkan. Majalah-majalah itu lazimnya diterbitkan kerana tanggungjawab untuk menyebarkan dakwah, bukannya untuk mencari keuntungan. Tidak hairanlah kebanyakan majalah agama diterbitkan oleh persatuan atau organisasi bersifat keagamaan, meskipun penerbit persendirian juga menerbitkan majalah seperti ini sebagai percubaan. ${ }^{6}$

Tulisan ini akan menghuraikan kecenderungan agama dalam penerbitan majalah Melayu sebelum Perang Dunia Kedua. Apakah kaitan majalah sedemikian dalam konteks perkembangan majalah Melayu secara keseluruhan? Bagaimanakah pula profil dan kedudukan majalah yang berkenaan? Akhirnya, adakah penerbitan majalah sedemikian memperoleh dukungan pembaca?

\section{Persoalan Agama Dalam Permajalahan Melayu}

Majoriti majalah Melayu sebelum Perang Dunia Kedua menjadikan agama sebagai elemen yang lazim diselitkan untuk menarik pembaca. Biarpun orientasi majalah itu hiburan seperti Hiboran Hari Raya (1935) dan Taja Penghiboran (Sep 1934) atau kesusasteraan seperti Kesah Malik Saif Bin Zi Yazin (20 Sep 1934) dan Kawan Berchakap (12 Dis 1934) atau pengetahuan umum seperti Al-Hikmah (Apr 1934), namun soal-soal berhubung agama Islam seperti kisah-kisah nabi, al-Quran dan hadis, pendidikan Islam, akhlak, dan sebagainya tetap disiarkan. Hal ini mungkin ada hubungannya dengan matlamat majalah-majalah itu diterbitkan. Kebanyakannya diterbitkan bukan semata-mata untuk memperoleh keuntungan, tetapi sebagai alat untuk memberikan didikan dan panduan kepada khalayak pembaca. Atas kecenderungan itu, tidaklah menghairankan jika jumlah majalah yang secara hakiki atau sebahagian besar kandungannya tentang agama cukup banyak diterbitkan, iaitu 24 buah (20\%) dalam tempoh sebelum Perang ini. Di samping itu, sebahagian besar majalah umum dan majalah yang diterbitkan oleh organisasi turut mengeksploitasi unsur agama dalam penerbitan masing-masing, walaupun tidak dominan. Atas alasan itu, diyakini bahawa agama merupakan teras dalam permajalahan Melayu sebelum Perang Dunia Kedua.

Sebelum majalah agama dibincangkan dengan lebih lanjut, tentunya ruang yang istimewa wajar diberikan kepada Pengasoh atas sifatnya sebagai majalah paling tua dalam dunia permajalahan Melayu. Pengasoh diterbitkan pada 11 Julai 1918 dan masih bertahan sehingga kini, meskipun dalam kekerapan yang tidak konsisten. Sebagai majalah Melayu 
paling tua, kedudukan Pengasoh agak istimewa. Hal ini ditambah pula dengan pengaruh yang dibawanya dan liku-liku dalam perkembangan penerbitannya sendiri. Malahan majalah ini menyaksikan penglibatan pertama kerajaan dalam penerbitan majalah Melayu. Pengasoh juga merupakan majalah berkala pertama diterbitkan di Negeri-Negeri Melayu Tidak Bersekutu walaupun Roff mengkreditkannya sebagai yang pertama di luar Negeri-Negeri Selat. ${ }^{7}$

Tidak bermula sebagai majalah, tetapi akhbar Pengasoh mengalami pasang surut yang cukup panjang dan berliku. Daripada akhbar dwimingguan, Pengasoh diubah kepada mingguan pada $1932^{8}$ sebelum penerbitannya terhenti pada akhir 1937 akibat kemelesetan ekonomi dan langkah jimat-cermat yang diambil oleh Majlis. ${ }^{9}$ Selepas Perang Dunia Kedua, Pengasoh dihidupkan semula dengan Hj. Muhamad Adnan menjadi editornya sehingga 1953 apabila Hassan $\mathrm{Hj}$. Muhamad mengambil alih jawatan tersebut. Selepas itu Pengasoh terhenti lagi sebanyak tiga kali sebelum mencapai kedudukannya kini sebagai majalah Melayu paling tua diterbitkan.

Diterbitkan oleh Majlis Ugama Islam dan Istiadat Melayu Kelantan, Pengasoh pada asalnya dijual dengan harga RM0.15. Barisan pengarangnya yang diketuai oleh Dato' Hj Muhamad Hj. Mohd Said ${ }^{10}$ atau Dato' Bentara Jaya menetapkan Pengasoh sebagai Warta Majlis Ugama Islam dan Istiadat Melayu Kelantan, dan dengan demikian memuatkan perkembangan yang berlaku di dalam Majlis, fatwa-fatwa yang dikeluarkan, soal kutipan zakat, pengurusan masjid-masjid, dan hal-hal rasmi yang lain. Lapan halaman yang diperuntukkan kepada Pengasoh mungkin terlalu panjang untuk mengehadkan kandungannya pada perkara-perkara rasmi sahaja, sehingga lama-kelamaan kandungannya mula diubah, sesuai dengan pandangan pembaca. Ruangan-ruangan seperti tafsir al-Quran dan hadis, isu-isu agama semasa, sejarah, khutbah Jumaat, dan kisah-kisah nabi yang menjadi baku dalam penerbitan agama mula mendapat tempat di dalam Pengasoh.

Kehadiran Pengasoh berkebetulan dengan suasana pemikiran di dunia Islam yang sedang mempersoalkan pendekatan dan pelaksanaan Islam dalam perspektif dan rangka modenis-reformis. Pada ketika ini ulamaulama Kaum Muda cuba membawa pembaharuan dalam ajaran Islam. Mereka berusaha untuk membawa masyarakat Melayu supaya kembali kepada ajaran Islam sebenar yang berlandaskan al-Quran dan hadis di samping mengamalkan ijtihad. Namun usaha ini mendapat tentangan daripada Kaum Tua yang tidak mahukan pembaharuan. Dalam polemik ini, Roff ${ }^{11}$ cenderung menyatakan bahawa Pengasoh, dalam beberapa keadaan mendukung falsafah pegangan Kaum Tua, sementara Mohd Sarim ${ }^{12}$ cenderung berpendapat bahawa majalah itu menjadi platform 
kepada Kaum Muda. Beliau memberikan tiga alasan untuk mengukuhkan pendapatnya itu. Yang pertama, kandungan Pengasoh cenderung pada membangunkan masyarakat dan dengan demikian ciri-ciri keislahannya dikemukakan secara terbuka. Yang kedua, meskipun Pengasoh menjadi lidah rasmi Majlis Ugama Islam dan Istiadat Melayu, namun Majlis tidak memonopoli kesemua ruangan di majalah itu. Majlis hanya diperuntukkan ruangan khas untuk menyiarkan siri syariah berupa fatwa dan soal jawab agama. Alasan yang ketiga ialah bahawa Pengasoh turut menyiarkan rencana tulisan tokoh-tokoh islah seperti Syeikh Tahir Jalaluddin dan Za'ba. Malahan A. Rahim Kajai yang kuat menentang pegangan Kaum Tua turut pernah menjadi penolong pengarang majalah itu.

Selamanya Pengasoh lebih berpegang pada tradisi, termasuklah perspektif editorialnya dalam isu-isu yang dihadapi masyarakat. Sewaktu majalah-majalah lain yang terdahulu dan terkemudian seperti Al-Imam, Neracha, dan Al-Ikhwan yang sering dikaitkan dengan reformasi cenderung mengutarakan pembaharuan dalam world-view masyarakat terhadap Islam, Pengasoh terus-terusan menyampaikan khutbah tentang dosa pahala dan neraka syurga kepada khalayak pembaca yang diselangseli dengan fatwa, soal-jawab agama, berita-berita ringkas, nasihat, dan sebagainya. Pendekatan tradisional Pengasoh ini bukan setakat pada kandungan editorial sahaja, malahan merebak pada amalan penyediaan editorialnya. Tulisan atau karya yang disiarkan dipastikan daripada hasil tulisan atau fikiran ulama dan pengarang yang terkenal dan berwibawa. Antara ulama yang memberikan sumbangan pada peringkat awal itu ialah Tok Kenali. ${ }^{13}$

\section{Peranan Madrasah Dalam Penerbitan Majalah}

Selain Pengasoh, terdapat lebih 20 buah lagi majalah yang khusus memuatkan tulisan tentang keagamaan pada zaman sebelum Perang Dunia Kedua. Majalah-majalah agama ini dapat dibahagikan kepada tiga kategori, iaitu majalah-majalah yang berkait dengan institusi pendidikan terutamanya madrasah, majalah-majalah yang berkait dengan persatuan-persatuan atau kelab dan majalah-majalah agama yang diterbitkan oleh orang perseorangan dan penerbit swasta.

Kategori majalah yang pertama ialah yang diterbitkan oleh institusiinstitusi pendidikan, khususnya oleh madrasah. Secara hakiki, kebanyakan majalah terbitan madrasah adalah bercorak agama walaupun terdapat juga yang berbentuk pengetahuan umum. Madrasah yang cukup penting peranannya dalam pendidikan Islam ketika itu menjadi penerbit utama majalah-majalah agama ini. Majalah-majalah itu bukan diterbitkan semata-mata untuk pelajar madrasah berkenaan, 
tetapi ditujukan kepada masyarakat umum. Dengan itu, artikel dan bahan-bahan yang disiarkan menyentuh pelbagai persoalan agama semasa yang dihadapi masyarakat, di samping resipi lazim dalam majalah agama yang masih diikuti sehingga kini (penghujung abad ke-20) seperti kisah-kisah nabi, al-Quran dan hadis, fardu ain, pendidikan, sejarah, dan sebagainya. Antara majalah yang diterbitkan dalam waktu ini ialah Ar-Raja (1925-26) dan Dewan Pergaulan (1940-41) oleh Madrasah AlMasyhor, Pulau Pinang, Jasa (1927-31) oleh Madrasah Al-Atas, Johor Bahru, Temasek (1930) oleh Madrasah Al-Junied Al-Islamiah, ${ }^{14}$ Singapura, Panduan (1934-35) oleh Madrasah Al-Idrisiah, Kuala Kangsar, Bintang Malaya (1939-41) oleh Kuliah Al-Firdaus, Singapura, dan Seruan Ihya (1941) oleh Madrasah El-Ehya As-Syarif, Gunung Semanggol. Melainkan Temasik dan Bintang Malaya yang lebih bercorak pengetahuan umum, kesemua majalah itu adalah majalah agama.

Ar-Raja (11 Mac 1925) diterbitkan oleh Abbas Rafik bagi pihak Madrasah Al-Masyhor ${ }^{15}$ dan disunting oleh Yusof Rajihin dan pernah diurus oleh Osman Kalam, ${ }^{16}$ salah seorang tokoh persuratkhabaran Melayu sebelum Perang yang penting. Dinyatakan bahawa:

Majalah ini terjauh sekali daripada mengkhidmatkan segala yang tiada baik dan yang dilarangi oleh agama dan akal, ialah semata-mata tujuannya mengkhidmatkan akan umatnya pada mencapai kemuliaan dan kebesaran khasnya pada agamanya. ${ }^{17}$

Majalah bulanan 28 halaman dan berharga RM0.35 ini menyiarkan tulisan-tulisan bercorak agama seperti ibadat, roh, cerita-cerita nabi, tajwid, dan belajar bahasa Arab. Tidak jelas kepada kita tarikh yang tepat majalah yang dicetak 500 naskhah ini diberhentikan, tetapi menjelang akhir tahun 1928, majalah ini sudah tidak diterbitkan lagi. Dua belas tahun kemudiannya, madrasah yang sama menerbitkan Dewan Pergaulan pada Mac 1940. Tiada pendukung Ar-Raja yang turut terlibat dalam penerbitan majalah ini. Penanggungjawabnya kali ini ialah Sheikh Ali Abdullah dan pengarangnya, Aman Shah Bukhari. Harga majalah ini jauh lebih murah daripada Ar-Raja, iaitu RM0.15 walaupun dengan 40 halaman, sedangkan RM0.35 untuk 28 halaman bagi majalah yang digantikannya itu. Dewan Pergaulan menyiarkan tulisan-tulisan berhubung pengetahuan tentang Islam dan perkara umum. Antara ruangan yang lazim disiarkan ialah ada-ada saja, renungkanlah, halaman tarikh, penggilap akal, nanti sebentar, cerita, dan berita penyunting. Dinyatakan bahawa:

Majalah ini ialah tempat perhimpunan fikiran, pemandangan dan pengetahuan dan bolehlah Dewan Pergaulan menjadi suatu bacaan yang sesuai dengan masa dan dipersetujui umat Melayu khasnya dan kaum Islam amnya dan boleh mendatangkan faedah yang diidami kelak. Turut 
dinyatakan adalah dikehendaki dengan Dewan Pergaulan ialah tempat perhimpunan fikiran, pemandangan dan pengetahuan. Kita dengan perasaan ikhlas menjemput segala penulis-penulis yang berperasaan dan ahli-ahli fikiran yang bijaksana memaparkan segala soal-soal yang berkenaan dengan masyarakat, buah fikiran-fikiran, pemandangan dan pengetahuan di dalam majalah yang muda rumaja ini. ${ }^{18}$

Di Johor Bahru, Madrasah Al-Atas ${ }^{19}$ menerbitkan Jasa pada 29 November 1927 dengan orang yang bertanggungjawab terhadap pengurusan dan penyediaan editorialnya ialah Syed Zain Hassan AlAtas yang mungkin merupakan guru utama di madrasah tersebut. Tidak banyak keistimewaan majalah ini berbanding majalah-majalah agama lain. Walau bagaimanapun, inilah majalah agama yang pertama memuatkan kadar jualan iklan untuk majalah, yang menunjukkan kesungguhan penerbit untuk mengeksploitasi sumber pendapatan lain, selain sirkulasi. Harga iklan satu halaman untuk majalah ini ialah RM10.00, setengah halaman RM4.50, satu perempat halaman RM2.50, dan satu perlapan RM1.50. Seperti majalah lain, Jasa menyiarkan bahanbahan yang lazim untuk majalah agama semasa, dan pada September 1931, majalah berharga RM0.25 ini terhenti penerbitannya.

Panduan pula diterbitkan di Kuala Kangsar pada November 1934 oleh Hj. Mohammad bagi pihak Madrasah Al-Idrisiah. Tenaga penggerak majalah ini ialah guru-guru madrasah dan anak muridnya dengan $\mathrm{Hj}$. Mohd Noor Faiz sebagai pengarang. Majalah bulanan 32 halaman berharga RM0.20 ini pada asasnya menyiarkan tulisan bercorak agama sesuai dengan motonya "Majallah ugama, pelajaran, fikiran, tawarikh, dan kemajuan" walaupun terdapat juga tulisan-tulisan umum di luar persoalan agama. Matlamat Panduan dapat dikesan daripada surat pengarang kepada Sultan Perak yang disiarkan di majalah itu:

...dapat patik-patik menyempurnakan tuntutan agama Allah dan mengibarkan panji-panji pengetahuan ke seluruh Alam Melayu dengan cara yang tidak menggendalai pelajaran patik-patik yang di dalam madrasah. ${ }^{20}$

Di Semanggol pula, Madrasah El-Ehya Al-Sharif menerbitkan Seruan Ihya pada Mac 1941. Majalah ini tidak dapat diterbitkan lebih lama kerana meletusnya Perang Dunia Kedua. Sebelum itu, pada Julai 1935, bekas murid-murid Madrasah Al-Syariff Al-Wataniah, Kepala Batas, Seberang Perai menerbitkan Al-Hikmah pada setiap penggal persekolahan. Berbeza dengan Al-Hikmah di Kota Bharu yang menyiarkan cerita-cerita mata gelap dan hiburan yang dihiasi dengan gambar-gambar seksi, Al-Hikmah ini menyiarkan petikan teks agama dan terjemahan cerita-cerita daripada 
bahasa Arab. Tumpuan pembaca majalah ini ialah para pelajar Melayu, khasnya mereka yang bersekolah pondok.

Majalah-majalah yang kita bincangkan itu diterbitkan oleh madrasah sama ada sebagai satu platform guru-guru atau pelajarnya untuk menyebarkan ilmu kepada masyarakat atau sebagai alat untuk memberikan kesedaran atau sekadar suatu usaha untuk memperoleh punca pendapatan kepada madrasah. Matlamat yang pertama itu mungkin lebih diberikan keutamaan berdasarkan tumpuan yang lebih lazimnya diberikan pada soal-soal penyediaan editorial. Persoalan yang berkait dengan pemasaran, penjualan, dan pengedaran lazimnya dikesampingkan. Hal ini timbul disebabkan pelbagai masalah yang tonggaknya bermula daripada latar belakang peneraju majalah itu sendiri yang lebih mementingkan elemen editorial daripada periklanan dan sirkulasi. Itulah tiga tiang, iaitu editorial, sirkulasi, dan iklan yang membolehkan sesebuah majalah bertahan di pasaran.

Soal mengapa majalah-majalah agama yang diterbitkan tentunya sedia difahami berdasarkan orientasi pendidikan dan matlamat madrasah-madrasah yang terlibat. Namun tidak kesemua madrasah yang melibatkan diri dalam penerbitan memilih untuk menerbitkan majalah agama. Dalam dua kes, majalah umum juga diterbitkan oleh madrasah dan ini menunjukkan bahawa soal komersial, bukan semata-mata spiritual, turut diambil kira dalam penerbitan majalah oleh madrasah ini. Temasik (Mac 1930) dan Bintang Malaya (1 Jun 1939) merupakan contoh majalah yang dimaksudkan itu. Kedua-dua majalah tersebut lebih banyak menyiarkan tulisan bercorak umum dan tidak terikat dengan elemen keagamaan.

Temasek diterbitkan oleh Regal Press, Haji Lane, Singapura dan disunting oleh Hj. Mohd Kassim Bakry. "Majalah Pelajaran, Pendidikan, Pengetahuan, Rampaian, Perkhabaran dan Cerita-cerita" ini menyiarkan tulisan berbentuk pengetahuan umum dengan antara ruangan yang lazim ialah sejarah Singapura, pelajaran dan pendidikan, jenaka, rampaian, gurindam, perkhabaran dan penyiasatan, cerita-cerita, dan pelajaran ilmu bumi. Majalah ini tidak menyiarkan sebarang gambar dan bertujuan '... akan menambahkan surat 2 bacaan yang bersangkut-paut dengan pelajaran hidup bangsa kita'. ${ }^{21}$ Majalah ini menjadi suara Madrasah Al-Junied, Singapura yang diasaskan oleh Syed Abdullah Omar pada 1927 dan dikelolakan oleh Fadhullah Suhaimi. Menurut Roff pengarang majalah ini adalah seorang Indonesia yang aktif dalam gerakan nasionalisme di negara tersebut. ${ }^{22}$

Bintang Malaya pula diterbitkan dan disunting oleh Hj. Abdul Hamid Fadzil di Singapura sebelum dipindahkan ke Muar pada Jun 1940. Penerbitannya terhenti pada Oktober 1940, tetapi diterbitkan kembali pada Mei 1941 sehinggalah terhenti terus akibat Perang pada akhir tahun itu. 
Majalah ini pada umumnya menyiarkan tulisan-tulisan berbentuk keagamaan dan pengetahuan umum. Antara ruangan yang lazim disiarkan ialah panduan hidup, gemala hikmat, rencana-rencana umum, tafsir alQuran, panduan guru, ruangan kaum ibu, puisi, gambar-gambar, halaman cerita, halaman perempuan, dewan belia, dan halaman agama.

Bagaimanapun, kebanyakan majalah agama yang diterbitkan oleh madrasah tidaklah mendapat kedudukan yang istimewa. Pengedarannya terbatas di kawasan atau negerinya sahaja. Yang ketara, setiap madrasah yang ada berusaha untuk menerbitkan majalahnya sendiri supaya nama madrasah akan dikenali umum. Majalah menjadi alat untuk mempromosikan madrasah berkenaan. Perlumbaan menerbitkan majalah ini menjadikan sifat-sifat asas dalam penerbitan sering diabaikan. Yang diberi penekanan ialah soal editorial, iaitu keupayaan penerbitnya untuk menyediakan bahan-bahan tulisan yang boleh disiarkan. Tugas itu bukanlah terlalu sukar. Banyak kitab, akhbar dan majalah daripada bahasa Arab yang boleh diterjemahkan atau diubahsuai supaya sesuai dengan cita rasa pembaca.

Dua buah majalah terjemahan sepenuhnya tetapi bukan diterbitkan oleh madrasah ialah Al-Kitab (Sep 1920) dan Puncha Pertikaian Ulama Islam (Nov 1929). Al-Kitab menyiarkan tulisan-tulisan tentang agama seperti sejarah Islam, tafsir, pendidikan, cerita-cerita nabi, bahasa Arab, dan sebagainya yang diterjemahkan dengan penyesuaian daripada kitab al-Quran versi Maulvi Muhammad. Puncha Pertikaian Ulama Islam pula ialah majalah bulanan di Pulau Pinang terbit pada November 1929 yang merupakan terjemahan daripada kitab Bidayatul Mujtahid Wa Nihayatul Muqtasid karya Ibn Rushd. Sebuah majalah lagi, Kesah Malik Saif Bin Zi Yazin (20 Sep 1934) yang terbit di Alor Setar merupakan saduran daripada cerita-cerita tradisional Parsi.

Soal pelanggaran hak cipta tidak banyak difikirkan kerana lazimnya pengarang-pengarang kitab berkenaan yang kebanyakannya dari Timur Tengah sering menganggap karyanya adalah sebahagian daripada jihad untuk agama, dan mereka tidak mempersoalkan faedah komersial daripadanya. Justeru, soal penterjemahan, pengubahsuaian, dan penyaduran daripada kitab-kitab Arab ke dalam penerbitan Melayu menjadi suatu kelaziman, dan percuma pula. Berita-berita tentang perkembangan Islam di sana sini boleh diterjemahkan sahaja daripada surat-surat khabar yang dibawa masuk dari Kaherah atau London.

Penyediaan editorial kurang diberi perhatian sehingga bahan-bahan yang disiarkan tidak mampu menarik minat pembaca. Tambahan pula, matlamat utama majalah-majalah seperti itu diterbitkan adalah untuk memenuhi matlamat sosial dan spiritual penerbitnya, sedangkan matlamat komersial, walaupun ada kurang diberi penekanan. Dua tiang lagi dalam 
penerbitan majalah, iaitu sirkulasi dan iklan sering diabaikan. Majalahmajalah yang diterbitkan itu sukar dijual kerana persaingan daripada majalah lain atau kerana pembacanya terlalu terbatas. Iklan pula sukar dicari kerana demografi pembaca majalah yang kurang menarik dan kekurangan usaha yang bersungguh-sungguh untuk penerbit menjual ruang-ruang majalahnya kepada pengiklan. Dengan demikian, kebanyakan majalah yang diterbitkan oleh madrasah ini tidak panjang usianya dan dicetak dalam jumlah yang sedikit pula.

\section{Majalah Oleh Pertubuhan Sosial}

Selain madrasah, majalah agama juga diterbitkan oleh pertubuhan bersifat sosial. Majalah-majalah ini lazimnya bukanlah semata-mata menjadi suara rasmi kepada persatuan yang menerbitkannya, tetapi kandungannya ditujukan kepada masyarakat umum. Kebanyakan majalah sebegini menggunakan pendekatan Islam sebagai konsep asas penerbitannya. Pada dekad 20-an, beberapa buah kelab menerbitkan majalah sendiri yang pada mulanya dimaksudkan untuk bacaan anggotaanggotanya, tetapi dalam banyak hal kemudiannya kelihatan merupakan alat perantaraan bagi khidmat kelab-kelab itu kepada masyarakat seluruhnya.

Secara umum, majalah seperti ini terbahagi kepada dua, iaitu yang diterbitkan oleh persatuan-persatuan kebudayaan dan kebajikan, dan yang diterbitkan oleh institusi pendidikan dan persatuan guru. Pertubuhan yang menerbitkannya yang dinamakan "progress association" oleh Roff merupakan persatuan sukarela dengan pelbagai matlamat masing-masing dan lazimnya berusaha untuk mempertingkat kebajikan dan kehidupan anggota-anggotanya dan seterusnya masyarakat Melayu. Pertubuhan ini yang tindakan masing-masing kurang berfokus, lazimnya menerbitkan majalah atau akhbar sebagai suara rasmi masing-masing. Dwi-mingguan Lidah Teruna (Jun 1920) diterbitkan oleh Persekutuan Perbahathan Orang-orang Islam Muar di Johor, iaitu antara persatuan sukarela Melayu yang pertama menerbitkan majalah. Orang yang paling bertanggungjawab menggerakkan majalah ini ialah pengarangnya sendiri, Abdullah Mohd Taib. Syarikat "pelelong dan penaksir dan pajak-memajak" yang dimilikinya sering memenuhi ruang iklan di majalah itu. Biarpun majalah ini mempunyai wakil-wakil penjual di Singapura (Hj. Muhamad Siraj), ${ }^{23}$ Terengganu (Yunos Noh), Ipoh (Muhamad Ali), dan Kota Setar (Hj. Abdul Hamid Imam Al-Hindi), namun jangka hayat majalah ini pendek. Lidah Teruna yang menggunakan moto "Majalah ilmu, adab, tarikh, nasihat, kesihatan, riwayat, dan perkhabaran" menggabungkan butiran-butiran itu yang disertai pula berita-berita pilihan dari dalam atau luar negeri yang dirasakan penting 
diketahui para pembacanya. Walau bagaimanapun, majalah yang dijual RM0.20 senaskhah ini terhenti penerbitannya pada 24 Januari 1921.24

Sebelum itu, Persekutuan Keharapan Belia di Johor Bahru menerbitkan Harapan pada Jun 1919. Tujuh tahun selepas itu, Persekutuan Guru-guru Islam, Muar (yang kemungkinan sebahagian anggotanya telah turut menganggotai Persekutuan Perbahathan yang disebut sebelum ini) menerbitkan majalah bulanan Lembaran Guru. Lembaran Guru disunting oleh Yaacob Arshad dan turut diuruskan oleh Hj. Nadzain Hj. Abdul Jamik sebagai nazir dan Muhammad Hj. Idris sebagai setiausaha. Barisan penolong pengarangnya terdiri daripada $\mathrm{Hj}$. Othman Hj. Mohd Said, Mohd Nor Sulaiman, Hawa Dupa, dan Muhammad Hj. Idris. ${ }^{25}$

Majalah bulanan berharga RM0.40 ini menjadi suara Guru-guru Islam Muar. Penasihatnya ialah Hj. Anda Hj. Abdul Jama'. Antara ruangan yang lazim disiarkan ialah tarikh, nasihat kanak-kanak, jenaka, budi dan perangai, hukum yang adil, khabar luar negeri, rahsia ketinggian, pesanan, cerita, kesihatan, kewajipan, dan perempuan. Dinyatakan bahawa:

Tentulah kandungan majalah ini penuh dengan buah-buah fikiran dan makalah dari rakan-rakan kami daripada guru-guru yang di dalam Semenanjung Tanah Melayu ini, terutama saudara kami di Alam Johor seperti guru-guru Johor Bahru, Batu Pahat, Mersing, dan lain-lain." Tujuan majalah ini diterbitkan dijelaskan pengarangnya demikian:"... dengan kasad hendak menunjukkan suatu perkhidmatan. Maka sekiranya kerana malapnya dan kecilnya itu tiada dapat ia menyinarkan cahaya yang membersihkan dan memuaskan mata yang melihat akan dia sekalipun, tetapi jadi penambah bilangan bintang-bintang yang telah sedia memancarkan sinaran cahayanya yang bersih itu ke seluruh Alam Melayu ini pun jadila. ${ }^{26}$

Orientasi majalah ini lebih kepada umum, melainkan satu dua ruangan bercorak agama seperti "budi dan perangai" dan "kewajipan". Majalah yang bercorak agama hakiki diterbitkan oleh persatuanpersatuan seperti itu ialah Al-Johoriah. Diterbitkan pada Oktober 1932 oleh sebuah pertubuhan yang menamakan dirinya sebagai Pakatan Islam Johor atau Al-Jamaah al-Islamiah al-Johoriah, Al-Johoriah menjadi suara rasmi persatuan itu di samping turut menyiarkan tulisan-tulisan berbentuk agama yang menjadi standard semasa untuk majalah sejenisnya ketika itu. ${ }^{27}$

Selain itu, sebuah persatuan guru-guru di sekolah-sekolah agama yang mendakwa meliputi Semenanjung Tanah Melayu, tetapi berpusat di Madrasah Al-Masyhor Pulau Pinang, iaitu Jemaah Guru-guru Ugama Semenanjung menerbitkan Wihdatul Madaris pada Oktober 1935. Dengan motto "Majalah ilmiah, madrasiah, dinniah, tarikhiah", nama majalah 
ini dengan sendirinya memberikan imej agama yang kukuh. Tujuan majalah ini diterbitkan adalah untuk:

... menggemarkan kepada menuntut ilmu, menguatkan ikatan muhibah di antara guru-guru sekolah Arab, menyeru sekalian ikhwan al-Muslimin kepada kemajuan di medan kehidupan menurut syarak, mendidik anakanak murid dan meluaskan pengetahuan mereka itu, mengenalkan sekalian ikhwan Muslimin dengan perjalanannya sekolah-sekolah Arab dan aturan pelajaran di dalamnya, dan melatih kanak-kanak dalam ilmu karang-mengarang bahasa Arab dan Melayu ${ }^{28}$

\section{Majalah Agama Oleh Penerbit Persendirian}

Jenis majalah agama yang terakhir ialah majalah yang diterbitkan oleh orang perseorangan dan penerbit swasta yang menerbitkannya sebagai suatu usaha dagang. Kebanyakan penerbit swasta ini merupakan pencetak atau maktabah dan dengan demikian, mereka juga bertindak sebagai pencetak majalah berkenaan. Memandangkan kebanyakan mereka ini terdiri daripada pencetak, maka dapat dijangka bahawa tujuan mereka menerbitkan majalah adalah untuk komersial. Majalah agama yang paling awal, Majallah Al-Islam (30 Jan 1914) diterbitkan oleh Abdul Kadir Yunus bagi pihak sebuah pencetak, Al-Ikhwan Press ${ }^{29}$ di Singapura. Pengarang majalah ini K. Anang adalah juga kakitangan editorial Tunas Melayu dan beliau merupakan pengarang Islamic Review edisi Indonesia. Dengan demikian edisi di Tanah Melayu itu adalah ubahsuai daripada edisi majalah tersebut yang pada asalnya merupakan terjemahan daripada majalah Al-Deen yang terbit di India.

Semangat Islam pula diterbitkan oleh Abdul Latief Hamidi yang turut menjadi pengarangnya. Majalah ini merupakan 'majalah bulanan menyeru kepada persatuan dengan pengetahuan Islam" dan "...memperhatikan kemajuan Islam dan meluaskan pemandangan bagaimana riwayat Islam' ${ }^{30}$ Berbanding kebanyakan majalah lain sezaman yang pasarannya terbatas di dalam negeri, Semangat Islam diedarkan hingga ke Hindia Belanda. Atas sambutan dari luar negeri yang diterimanya itu, majalah tersebut memperuntukkan satu ruangan khas bertajuk "Perkhabaran Indonesia" dan pengarang melayani pembaca kedua-dua wilayah dengan menyuarakan idea-idea dan seruan untuk menyatupadukan umat Islam, di samping merangsangkan pembaca ke arah tercapainya kemajuan dan keamanan hidup bersama. Nada pengarang cenderung kepada semangat pembaharuan atau islah walaupun kurang dominan. Pengarang berhatihati supaya kandungan yang disiarkan tidak menyinggung majalah atau akhbar yang lain. Pengarang menyatakan bahawa:

Tiadalah patut Semangat Islam ini mencampuri urusan politik kerajaan 
ataupun cerca-mencerca atas diri seseorang yang khas ataupun di dalam masalah furuk agama kerana itu sekali-kali tiadalah Semangat Islam akan membawa hal tersebut. ${ }^{31}$

Semangat Islam sering juga mendapat sumbangan artikel daripada pelajar-pelajar Al-Azhar di Kaherah dan sering pula menyiarkan tulisantulisan tentang peristiwa di Timur Tengah, di samping Indonesia. Keadaan ini mengingatkan kita kepada dua buah majalah Melayu yang diterbitkan oleh pelajar-pelajar Melayu dan Indonesia di Kaherah dan disebarkan secara meluas di Semenanjung walaupun di Indonesia, keduaduanya diharamkan. Majalah-majalah yang mengupas hal-ehwal agama di samping mencela pihak penjajah dengan pedas dan berani itu ialah Seruan Azhar (1925-28) dan Pilehan Timor (1927-28)..$^{32}$

Pada masa yang sama, sebuah lagi majalah agama diterbitkan di Pulau Pinang, iaitu Puncha Pertikaian Ulama Islam. Diterbitkan oleh Syarikat Ittihadiah, Kajang Road, majalah yang menggunakan motto "Mengandungi ijtihad, istidlah, ikhtilaf, ijmak, dan tarikh ulama Islam" disunting oleh dua orang, iaitu Hj. Asbiran Yaakob dan Hj. Abdul Halim Sabir dua orang yang tidak mempunyai latar belakang dalam penerbitan sebelum dan sesudah itu. Puncha Pertikaian Ulama Islam terhenti penerbitannya pada November 1930. Majalah ini sebenarnya merupakan terjemahan daripada sebuah kitab karangan Ibn Rushd, Bidayatul Mujtahid Wa Nihayatul Muqtasid, dan seperti juga kebanyakan majalah semasa lainnya, majalah ini dicetak 1,000 naskhah. Dalam ruangan pengenalannya pengarang menyatakan:

...adalah ilmu yang jarang diketahui oleh putera Melayu ialah ilmu yang berkenaan dengan pendapatan dan pertikaian imam-imam mujtahid pada hukum-hukum agama. Oleh yang demikian kami curahkanlah perusahaan dan cita-cita bagi mengutip dan menyusunnya dalam bahasa Melayu daripada kitab Bidayatul Mujtahid karangan ulama Ibn Rushd yang mana sebuah kitab yang lengkap dan ringkas serta elok susunan ibaratnya berkenaan dengan segala mazhab imam-imam mujtahid dan pengambilannya daripada asal-usul agama... Maka kitab ini kita namakan Puncha Pertikaian Ulama Islam kerana kebanyakan pembicaraannya ialah pertikaian mereka itu serta sebab-sebabnya. Dengan jalan ringkas kami suntingkan pula ke dalamnya segala tarikh ulama Islam yang tersebut. ${ }^{33}$

Di Kota Bharu, Matbaah Al-Kamaliah menerbitkan Mujallah AlKamaliah pada 1 Januari 1930 dan mampu bertahan sehingga meletusnya Perang. Majalah dwimingguan Al-Kamaliah ini yang walaupun menggunakan motto "Majallah tarikh, pelajaran, persatuan, 
pengetahuan ugama, perkhabaran", pada umumnya menyiarkan tulisantulisan berunsur keagamaan. Dalam bilangan kedua majalah itu umpamanya, antara tajuk artikel yang disiarkan ialah "Kejadian Adam A.S", "Al-Hadis", "Kesempurnaan jiwa", "Kisah nabi dan sahabat", "Kelebihan bulan puasa", dan "Kelebihan ulama"34. Daripada nada editorial dan bentuk tulisan yang disiarkan, majalah ini mewakili imej Kaum Muda dalam gerakan islah yang berlaku ketika itu. ${ }^{35}$

Agak lama selepas Mujallah Al-Kamaliah itu, tidak ada majalah agama diterbitkan oleh individu atau perusahaan swasta. Hanya madrasah dan persatuan-persatuan yang aktif menerbitkan majalah sedemikian sehinggalah Persama Press ${ }^{36}$ dan Hj. Abdul Aziz Sheikh Rahmat ${ }^{37}$ menerbitkan Pedoman Islam pada 19 April 1935 di Pulau Pinang. Majalah dwimingguan 24 halaman ini diterbitkan untuk membantu Al-Madrasatul Islamiah, Bagantuan Kecil, Seberang Perai dalam mendidik keagamaan di samping untuk menguruskan anak-anak yatim dan miskin. Sebagai sebuah majalah agama, Pedoman Islam memberikan tumpuan yang lebih kepada tiga bidang, iaitu tafsir al-Quran, hadis nabi, dan sejarah atau tarikh yang pada peringkat awal dipersembahkan dalam bentuk yang mudah, ${ }^{38}$ sebelum kemudiannya dihuraikan dalam bentuk yang panjang, sehingga kadangkala bersambung-sambung pada keluaran akan datangnya. Dalam rencana pengenalannya, pengarang menyatakan bahawa majalah ini:

...suatu risalah yang isinya pengetahuan semata-mata dengan tidak berisi perkhabaran dan kejadian-kejadian lain. Ilmu pengetahuan tetap selamalamanya menjadi ilmu pengetahuan. Oleh sebab itu sampai masa mana pun juga Pedoman Islam kita tetap tidak ada basinya. ${ }^{39}$

Pulau Pinang juga menyaksikan penerbitan sebuah majalah agama, Al-Islam (Jul 1936). Tidak jelas kedudukan sebenar penerbit majalah ini, hanya dinyatakan Pejabat Al-Islam, No. 232D, Langkawi Road, Pulau Pinang. Al-Islam disunting oleh Yusof Ahmad Lubis dan dibantu oleh Ibnu Hassan. Hj. Muhammad Ibrahim menjadi pengurus dan majalah ini dicetak oleh Persama Press, Acheen Street, Pulau Pinang. Pada umumnya, Al-Islam menyiarkan tulisan-tulisan berhubung agama Islam dengan antara ruangan tetapnya ialah seruan ke arah agama, kata pemimpin, surat kiriman, ibadat, dan tafsir hadis dan al-Quran, dan syair. Dinyatakan bahawa majalah ini:

Bagi seluruhnya umat Islam dan Al-Islam tanah airnya satu, kaum Muslimin dalam bahagia tetapi kelemahan pada pekerja. Engkaulah satusatunya terompet Al-Islam. Bekerjalah engkau, Tuhanlah yang melihat kerjamu itu. Al-Islam pertalian benua Islam dan pertalian yang utama di antara pembacanya. ${ }^{40}$ 
Majalah ini terhenti pada November 1936 dengan gabungan Bil. 4 \& 5 adalah yang terakhir. Pada bulan yang sama, Persahabatan sebuah majalah agama yang paling penting di Pulau Pinang diterbitkan. Majalah ini diterbitkan tiga kali sebulan, iaitu pada setiap 1, 11, dan 21 hari bulan. Pengarangnya ialah Mohd Yunus Abdul Hamid ${ }^{41}$ dan kebanyakan pembacanya dikatakan terdiri daripada guru-guru agama, murid-murid sekolah agama, dan alim ulama. ${ }^{42}$ Walaupun dalam keluaran percontohannya, dinyatakan bahawa majalah ini '...membawa perkhabaran, rencana dan buah-buah fikiran dari pengarang-pengarang yang tinggi-tinggi ilmu dan selidiknya daripada kaum-kaum yang bertamadun seperti Arab, Inggeris, dan lain-lainnya'. ${ }^{43}$ Namun penekanan yang lebih diberikan pada soal-soal agama.

Di Singapura pula, empat buah majalah agama diterbitkan oleh penerbit swasta, iaitu Kahidupan Dunia Akhirat (17 Sep 1935), Dunia Akhirat (Jul 1936), Medan Laki-Laki (27 Sep 1935), dan Medan Al-Islam (14 Ogo 1936). Kahidupan Dunia Akhirat diterbitkan oleh Mohd Ali Abdou bagi pihak Ahmad Press ${ }^{44}$ dan dicetak oleh Al-Islamiah Press. Majalah dwimingguan 28 halaman dan berharga RM0.15 ini "mengandungi riwayat dan cermin kehidupan dunia dan akhirat" dengan ruangan fatwa, halaman To' Ki yang mengandungi nasihat agama kepada pembaca, cerita-cerita teladan, alam perempuan, dan kisah-kisah nabi menjadi antara ruangan tetapnya.

Dinyatakan oleh penerbitnya bahawa majalah Kahidupan Dunia Akhirat 'semata-mata mengkhidmatkan diri kepada kaum bangsa dan agama dengan jalan menyiarkan buah-buah fikiran yang bersangkutan dengan kehidupan di dunia dan kesenangan di akhirat. Tujuan besar bagi majalah ini ialah untuk menerangkan perkara-perkara yang bersangkutan dengan syarat-syarat yang tersebut. ${ }^{45}$ Majalah ini tidak dapat bertahan lama di pasaran dan digantikan dengan Seruan Kebajikan (Ogos 1937). Penggantian nama majalah ini ada hubungannya dengan sebuah majalah lagi yang diterbitkan oleh penerbit, iaitu Dunia Akhirat yang jelas membayangi majalah yang pertama itu.

Walaupun Kahidupan Dunia Akhirat dan Dunia Akhirat diterbitkan oleh penerbit yang sama, namun pengarangnya berbeza. Tidak banyak yang kita ketahui tentang Mohd Ali Abdou berbanding pengarang Kahidupan Dunia Akhirat, Sulaiman Ahmad. Matlamat Dunia Akhirat adalah untuk menyebarkan ilmu kepada khalayak pembacanya. Dalam keluaran sulungnya, pengarang menyatakan tujuan majalah ini ialah '... semata-mata tujuan hendak memberi manfaat dan faedah yang berkenaan di dunia dan akhirat sebanyak sedikitnya dengan seberapa sahaja ada daya upaya istimewa kepada kaum Melayu khasnya dan umat Islam amnya'. ${ }^{46}$ 
Penekanan pengarang dan majalah ini ialah untuk mendidik pembaca akan pentingnya ilmu untuk memudahkan urusan agama dan hidup mereka. Pengarangnya menyatakan bahawa: Barang siapa yang berkehendakkan dunia hendaklah dia berilmu dan barang siapa berkehendakkan akhirat hendaklah dia berilmu, dan barang siapa berkehendakkan dunia dan akhirat, hendaklah dia berilmu, iaitu bagaimana yang telah disediakan oleh Rasulullah, demikian bunyinya ${ }^{47}$

Kandungan rencana pengarangnya dipenuhi dengan tulisan-tulisan yang tipikal untuk majalah-majalah agama semasa. Pada 10 Ogos 1936 umpamanya, antara judul ruangan yang terdapat di majalah ini ialah "Dunia akhirat", "Surat kiriman", "Berlagu-lagu membaca al-Quran", "Pemberi sedekah dan orang yang memintanya", "Pengaruh gambar", "Persaudaraan dalam Islam", "Peringatan", "Syarah surah al-Fatihah", "Halaman perempuan", dan "Halaman kanak-kanak", di samping ruangan-ruangan cerita pendek atau anekdot. Ruangan-ruangan tersebut adalah lazim dan standard sifatnya dalam majalah agama. Cuma yang membezakan satu majalah agama dengan yang lain ialah penulisnya dan bagaimana tulisan-tulisan seperti itu dipersembahkan. ${ }^{48}$

Medan Laki-Laki pula diterbitkan oleh Syed Ahmad Hussein Dahlan Al-Indonisi bagi pihak Royal Press ${ }^{49}$ yang kemudiannya turut menerbitkan Medan Al-Islam. Dengan motto "Majalah Mingguan Islam yang Pertama", Medan Laki-Laki tidaklah dikhususkan untuk kaum lelaki, sebaliknya meliputi kaum perempuan. ${ }^{50}$ Tujuan majalah ini ialah hendak memimpin kaumnya ke medan kebahagiaan dan kejayaan mengikut jalan yang dikehendaki oleh ugama Islam dan menghapuskan sekalian adat yang karutkarut yang telah menimpa kaumnya berates-ratus tahun itu. Penerbit tidak menyatakan rasional menggunakan judul majalah sedemikian, sesuai dengan firman Allah yang bermaksud, 'hendaklah ada di kalangan kamu suatu golongan (laki-laki) yang menyeru mengerjakan yang makruf (baik) dan mencegah daripada yang mungkar'. Namun begitu sejak awal-awal lagi, pengarangnya menyatakan bahawa:

Sekalipun majalah ini memakai nama laki-laki tiada lupa juga ia menyediakan suatu medan di dalamnya untuk kaumnya yang perempuan dengan nama Medan Perempuan yang mana sengaja diuntukkan bagi tempat pertandingan kalam penganjur-penganjur kaum ibu yang menaruh belas kasihan kepada bangsanya yang lemah lembut itu. ${ }^{51}$

Hampir dua tahun kemudiannya, Medan Al-Islam diterbitkan dengan barisan pendukung yang sama dengan Medan Laki-Laki. Majalah ini adalah sebagai menggantikan majalah yang awal itu, yang namanya mungkin kurang sesuai kerana membataskan potensi pembacanya. Sirkulasi majalah ini hanyalah 1,000 naskhah berbanding Medan Laki- 
Laki 1,500 naskhah. Ini menunjukkan bahawa penggantian nama majalah tidak membawa kesan yang positif terhadap survival majalah ini kerana tidak sampai dua tahun kemudiannya, majalah ini terpaksa diberhentikan.

\section{Persoalan Ekonomi Penerbitan}

Sebagai majalah yang diterbitkan dan dimodali oleh pihak swasta yang berharap pada untung dalam usahanya itu, sudah tentu majalah-majalah agama yang kita bincangkan itu mempunyai kelebihan berbanding saingannya yang diterbitkan oleh madrasah atau persatuan. Yang paling ketara ialah kesungguhan kalangan penerbit untuk mengeksploitasi punca pendapatan selain sirkulasi, iaitu iklan. Purata ratio iklan:editorial majalah-majalah ini lebih tinggi daripada saingannya itu, dengan umpamanya Dunia Akhirat mencapai ratio hampir 20:80 - satu kadar ratio iklan:editorial yang tinggi untuk sebuah majalah agama. Walau bagaimanapun, jangka hayat majalah-majalah agama jenis ini lebih pendek daripada madrasah atau persatuan. Hal ini mungkin didorong keputusan segera yang diambil oleh penerbit untuk menamatkan pengeluaran majalah setelah disedari usaha itu tidak viable disebabkan pasaran yang terbatas. Ini berbeza dengan majalah madrasah atau pertubuhan yang terus diterbitkan untuk beberapa waktu meskipun mereka terpaksa menanggung kerugian, semata-mata tanggungjawab sosial dan spiritual yang mahu dipikulnya.

Daripada sirkulasi majalah-majalah agama yang diterbitkan oleh penerbit swasta ini, nyata bahawa jumlahnya lebih banyak daripada yang diterbitkan oleh madrasah atau persatuan. Hal ini mungkin didorong oleh kesedaran yang lebih di kalangan pendukungnya terhadap soalsoal ekonomi penerbitan dan kewangan yang melibatkan perbelanjaan dan pendapatan. Rangsangan untuk menjual majalah yang diterbitkan mungkin lebih besar kepada para penerbit ini kerana sememangnya hidup mati syarikat bergantung pada pendapatan yang diperoleh daripadanya. Berbeza dengan majalah agama yang diterbitkan oleh madrasah atau persatuan, majalah yang diterbitkan oleh pihak swasta ini lebih bersungguh-sungguh dalam soal pengurusan dan pemasaran. Contoh yang paling jelas ialah kerapnya ingatan yang disiarkan oleh majalahmajalah ini kepada para wakil penjual dan pelanggan yang masih belum membuat pembayaran berbanding dengan majalah-majalah agama terbitan madrasah. Soal survival lebih menjadi perkiraan penting kepada penerbit, berbanding soal-soal spiritual atau sumbangan kepada bangsa dan agama yang cenderung menjadi pegangan penerbit madrasah dan persatuan. 
Memandangkan kandungan editorial majalah-majalah agama yang kita sebutkan itu lebih kurang sama dan dalam keadaan tertentu sama, iaitu apabila sumber yang sama diterjemah oleh dua majalah yang berlainan, maka yang membezakan sebuah majalah dengan yang lain bukan lagi aspek editorial, tetapi iklan dan sirkulasinya. Untuk meningkatkan sirkulasinya, usaha yang sering dilakukan ialah dengan mempromosikan majalah di dalam penerbitan lain. Banyak majalah yang memperuntukkan satu halaman untuk memberikan khabar kepada pembaca tentang majalah atau akhbar baru yang baru diterbitkan. Penerbit majalah baru hanya perlu menghantar majalah barunya sebagai hadiah kepada penerbit majalah berkenaan untuk diulas dan disiarkan dalam ruangan ini. Majalah-majalah seperti Mujallah Guru dan Al-Hikmah menyiarkan halaman ini secara tetap, sementara kebanyakan yang lain bergantung pada bahan yang mahu disiarkan.

Usaha lain yang kerap dilakukan ialah dengan mengadakan peraduan kepada pembaca dengan menawarkan pelbagai jenis hadiah daripada wang tunai kepada jam tangan. Sudah tentu kejujuran penerbit kita sangsikan apabila umpamanya majalah Dunia Akhirat bersedia menawarkan hadiah wang tunai RM75.00 kepada para pemenang teka katanya yang sehingga hayat majalah berharga RM0.25 itu berakhir, hadiah yang dimaksudkan tidak pernah dimenangi. ${ }^{52}$

\section{Kesimpulan}

Pada umumnya, majalah bercorak agama memang menjadi segmen yang utama dalam dunia permajalahan Melayu. Dalam periode sebelum Perang Dunia Kedua, 20 peratus daripada 120 buah majalah Melayu dapat dikategorikan sebagai majalah agama. Jenis majalah yang lain ialah kesusasteraan, diayah, pengetahuan umum, suara organisasi, dan majalah nasionalisme. Hal ini timbul kerana persoalan tentang keagamaan amat rapat hubungannya dengan demografi pembaca ketika itu.

Ramai dalam kalangan pembaca yang komited terdiri daripada pelajar atau guru-guru yang bernaung dalam sistem pendidikan pondok. Dalam beberapa kes, guru-guru sendirilah yang menjadi tulang belakang penerbitan majalah, terutamanya sebagai pengarang atau penyunting. Para pelajar pula terlibat secara langsung atau tidak langsung sebagai penjual majalah. Bagi majalah seperti Jasa dan Panduan yang diterbitkan secara langsung oleh institusi pendidikannya, sudah tentulah suara madrasah yang memerlukan keterlibatan langsung daripada pelajarpelajar dan guru-gurunya. Faktor inilah juga yang mungkin menjadi faktor akan panjangnya hayat sesetengah majalah agama ini. 


\section{Nota}

1 Hamedi Mohd Adnan, "Direktori majalah Melayu abad ke-20", Manuskrip yang belum diterbitkan.

2 William R. Roff, Bibliography of Malay and Arabic Periodicals Published in the Straits Settlements and Peninsular Malay States 1876-1941, London: Oxford University Press, 1972.

3 Muhammad Dato' Muda, Kitab Tarikh Surat Khabar, Bukit Mertajam: Az-Ziniah Press, 1941.

4 William R. Roff, The Origin of Malay Nationalism, Kuala Lumpur: Oxford University Press, 1975.

5 Abdul Ghani Ishak, Seruan Azhar: Bilangan 22 hingga 32 dirumi dan diedit, Latihan Ilmiah Jabatan Sejarah, Universiti Malaya, 1976, Lihat juga Mohammad Redzuan Othman, Islam dan Masyarakat Melayu, Kuala Lumpur: Penerbit Universiti Malaya, 2005.

- Hamedi Mohd Adnan, Ekonomi penerbitan majalah Melayu sebelum merdeka, Disertasi PhD, Jabatan Pengajian Media, Universiti Malaya, 2001

7 Roff membuat kesilapan dalam menyatakan demikian kerana sebelum Pengasoh, beberapa buah penerbitan pernah diterbitkan di negeri-negeri selain Negeri-negeri Selat. Antaranya ialah akhbar Seri Perak (1893) dan Jajahan Melayu (1896-97) di Taiping, dan Jambangan Warta (1901) di Batu Gajah, dan majalah-majalah Warta Kerajaan Perak (1897-1910) di Taiping, Khizanah Al-Ulum (1904) di Kuala Kangsar, dan Warta Perusahaan Tanah (1917-41) di Kuala Lumpur.

8 Pada 1932 Pengasoh diterbitkan secara mingguan pada setiap Isnin, tetapi diubah kepada hari Khamis pada 1934. Perubahan hari terbit ini ada hubungannya dengan jadual penghantaran Pengasoh ke luar Kelantan yang pada waktu itu menggunakan kereta api. Dinyatakan bahawa, "Oleh kerana pada masa ini tidak lagi berhajat kepada kita mengirimkan Pengasoh dengan mel kapal hanya lebih senang dan mudah dengan mel kereta api. Yang demikian kita ubahkan pengeluaran Pengasoh daripada hari Isnin kepada hari Khamis pula mengikut mel kereta api di sini." Pengasoh, Februari 1934, hlm. 16

${ }^{9}$ Program penjimatan perbelanjaan Majlis Ugama Islam dan Istiadat Melayu Kelantan (MUIIMK) mula dilakukan pada 1933 apabila beberapa jabatan ditutup dan kakitangannya diberhentikan. Bagaimanapun kurang jelas kepada kita sejauh mana langkah penjimatan perbelanjaan tersebut memberikan pengaruh terhadap kakitangan Pengasoh kerana kesannya hanya dirasakan empat tahun kemudiannya. Untuk program penjimatan perbelanjaan ini, lihat Majlis Ugama Islam dan Istiadat Melayu Kelantan, berkenaan dengan estimates gaji dengan perbelanjaan MUIIMK bagi 1933, Fail 260/33, Arkib Negara Malaysia.

${ }^{10}$ Dato' Hj Muhamad Hj. Mohd Said dilahirkan di Kampung Dalam Kubu, Kota Bharu pada 30 Januari 1888. Beliau mendapat pendidikan awal daripada ayahnya sendiri dan pada tahun 1902, beliau berangkat ke Makkah untuk berguru dengan Syeikh Nik Mat Kechik dan Syeikh Wan Ali Kutan. Selepas itu beliau melanjurkan pelajaran ke Mesir selama empat tahun dan belajar dengan Syed Jamaluddin AlAfghani dan Syeikh Muhammad Abduh. Muhammad balik ke Kelantan pada tahun 1914 dan setahun kemudiannya menubuhkan Majlis Ugama Islam dan Istiadat Melayu Kelantan bersama-sama Dato' Paduka Nik Mahmud Ismail dan 
Syeikh Mohd Yusuf Ahmad atau Tok Kenali. Pada tahun 1917 beliau menubuhkan Madrasah Al-Muhammadi dan apabila Pengasoh diterbitkan pada 11 Julai 1918, beliau menjadi ketua pengarangnya. Selain itu beliau juga menjadi pengarang $\mathrm{Al}-$ Kitab (14 Sep 1920). Pada tahun 1925 Muhammad dilantik menjadi Setiausaha Kerajaan Kelantan dan pernah juga menjadi pemangku Perdana Menteri Kelantan. Lihat Ensiklopedia Sejarah dan Kebudayaan Melayu, Kuala Lumpur: Dewan Bahasa dan Pustaka, 1991, hlm. 1581-82.

${ }^{11}$ William R. Roff, Bibliography of Malay and Arabic Periodicals, hlm. 99-105.

${ }^{12}$ Mohd Sarim Mustajab et al., Akhbar dan Majalah di Malaysia: Sejarah dan Perkembangan, Bangi: Jabatan Sejarah UKM, 1988, hlm. 43-47.

${ }^{13} \mathrm{To}^{\prime}$ Kenali atau Hj. Muhammad Yusof Ahmad dilahirkan di Kampung Kenali, Kubang Kerian pada tahun 1868. Beliau belajar menulis dan mengaji al-Quran daripada datuknya sebelum belajar pondok di Masjid Kota Bharu. Pada tahun 1886 beliau berangkat ke Makkah untuk meneruskan pengajian agamanya dan hanya balik ke Kelantan pada tahun 1908. Beliau terus mengajar agama di Kampung Paya dan dalam masa yang singkat mendapat perhatian daripada para pelajar dari seluruh negara. Pada tahun 1915 beliau dipelawa mengajar di masjid Kota Bharu dan lima tahun kemudian kembali mengajar di Kampung Kenali. To' Kenali dilantik menjadi pengarang kehormat Pengasoh dan menjaga ruangan "Soal Jawab Agama." Untuk penjelasan lebih terperinci tentang peranan dan ketokohannya, lihat Abdullah Al-Qari Hj. Salleh, "To' Kenali: His Life and Influence" dlm. William R. Roff, ed., Kelantan: Religion, Society and Politics in a Malay State, Kuala Lumpur: Oxford University Press, 1974, hIm. 87-100; Abdullah Al-Qari Hj. Salleh, Sejarah Hidup To' Kenali, Kota Bharu: Pustaka Aman Press, 1967; dan Abdul Rahman Al-Ahmadi, Tokoh dan Pokok Pemikiran Tok Kenali, Kuala Lumpur: Kementerian Kebudayaan, Belia dan Sukan, 1983.

${ }^{14}$ Madrasah ini ditubuhkan pada 1927 oleh keluarga Al-Junied di Singapura dengan Yang Dipertuanya, Tuan Syed Abdul Rahman Al-Junied dan pengetuanya, Tuan Syed Abu Bakar Toha. Bermula dengan 14 orang murid, pelajar madrasah ini bertambah kepada 170 orang pada 1930, dengan kira-kira 60 orang datang dari luar Singapura. Para pelajar diberi didikan secara percuma, dengan bahasa perantaraan Arab, dan pihak madrasah hanya menyediakan asrama bagi "tempat tinggal anak-anak dagang". Lihat Temasik, 1 Julai 1930, hlm. 16.

${ }^{15}$ Madrasah Al-Masyhor ditubuhkan pada 1914 dan Syed Syeikh Al-Hadi menjadi mudirnya pada 1915-1919. Madrasah ini memberi keutamaan dalam pelajaran bahasa Arab kepada murid-muridnya dan dikatakan mempunyai "aturan baharu yang boleh cepat kanak-kanak bertutur" bahasa tersebut. Selain Al-Hadi, guru yang terkenal di madrasah ini, yang kemudiannya menjadi mudir bagi menggantikan Al-Hadi ialah Syeikh Abdullah Maghribi. Sebahagian besar daripada guru dan penuntut madrasah ini pada peringkat awal terlibat secara langsung atau tidak langsung dalam gerakan Islam yang bertiup di Tanah Melayu waktu itu. Untuk perbincangan tentang peranan madrasah ini dan juga Syeikh Abdullah Maghribi dalam gerakan islah, lihat Mohd Sarim Mustajab, "Pendidikan dan Kaum Muda", Jebat, Bil. 5 \& 6, 1978, hlm. 1-6. Lihat juga William R. Roff, Malay Nationalism, hlm. 103. Madrasah ini juga mempunyai Jabatan Terjemahan atau Lujnah Al-Tarjamah wa Al-Tahrir yang dikendalikan oleh sebuah lembaga 
tujuh orang anggota. Jabatan ini diketuai oleh Ibrahim Mahmud yang turut bertindak sebagai penyunting. Anggota yang lain ialah Abdul Karim Isa, Syeikh Ali Abdullah Baldran, Syeikh Ahmad Abdullah Baldran, Muhamad Kassim Hassan, Ahmad Arif Yahya, dan Muhamad Mukhtar Abu Bakar. Lihat Md. Sidin Ahmad Ishak, Penerbitan dan Percetakan Buku Melayu 1807-1960, Kuala Lumpur: Dewan Bahasa dan Pustaka, 1998, hlm. 193.

${ }^{16}$ Osman Kalam dilahirkan di Padang Rengas, Perak pada awal abad ke-20 dan memperoleh pendidikan Melayu sebelum bersekolah Inggeris di Kuala Kangsar. Selepas menamatkan persekolahannya, beliau menjadi guru bahasa Inggeris di Madrasah Al-Masyhor, Pulau Pinang. Sewaktu bertugas di madrasah itu, beliau menjadi penolong pengarang Idaran Zaman dan mulai awal tahun 30-an beliau menceburi bidang kewartawanan sepenuhnya dengan menjadi pengarang akhbar Bahtera dan Bumiputera. Selepas kedua-dua akhbar itu diberhentikan, beliau berpindah ke Warta Malaya sebelum berpindah pula ke akhbar Majlis mulai Jan 1935 hinggalah menjelangnya Perang Dunia Kedua. Lihat William R. Roff, The Origin of Malay Nationalism, hlm. 218-19 dan Mohd Taib Osman, Bahasa Renchana Pengarang Akhbar-akhbar Melayu Hingga ke Tahun 1941, Kuala Lumpur: Dewan Bahasa dan Pustaka, 1964, hlm. 82.

${ }_{17}$ Ar-Raja, 11 Mac 1925, hlm. 3.

${ }^{18}$ Dewan Pergaulan, Mac 1940, hlm. 5.

${ }^{19}$ Madrasah Al-Attas dibuka pada 22 Disember 1937 oleh keluarga Al-Attas. Mudirnya ilah Syed Muhamad Hassan Al-Sahab sementara nazirnya, Syed Muhamad Hassan Al-Attas. Mereka dibantu oleh Syed Abdullah Hassan AlAttas dan Syed Salim Hassan Al-Attas. Dalam Lembaga, 2 Januari 1938, hlm. 4 ,dinyatakan bahawa madrasah ini mempunyai kelengkapan yang cukup untuk belajar bahasa Arab dan "... murid2 dijaga dan dikawali oleh seorang Arab penjaganya dengan sentiasanya bercakap bahasa Arab sahaja serta menjaga tingkah laku adab tertibnya" dan "... ada penjaga tukang kejut tidur daripada waktu pagi2 fajar kerana sembahyang Subuh dan menjaga mereka itu masa mereka membaca di antara Maghrib dan Isyak."

${ }^{20}$ Panduan, 20 November 1934.

${ }^{21}$ Temasek, Mac 1930, hlm. 3.

${ }^{22}$ Roff, William R., The Origin of Malay Nationalism, Kuala Lumpur: Oxford Univ. Press, 1975, hlm. 274.

${ }^{23} \mathrm{Hj}$. Muhammad Siraj merupakan penerbit dan penjual buku Melayu yang terbesar di Singapura sejak akhir abad ke-19 hinggalah awal tahun 1920-an. Beliau yang berketurunan Jawa dari Rembang memulakan kegiatan percetakannya pada tahun-tahun 1870-an sebelum mengembangkan perniagaannya sebagai penerbit dan kemudian sebagai peniaga buku. Hj. Muhammad Siraj yang pernah memangku jawatan editor Jawi Peranakan (1889-1891) beroperasi di No. 43, Jalan Sultan, Singapura. Sebagai peniaga buku yang terbesar di Singapura, beliau mempunyai ejen di Johor, Melaka, Pulau Pinang, Perak, Deli, Sandakan, dan Betawi. Pada tahun 1890-an beliau melantik kedai buku di Betawi, Albrecht \& Rusche sebagai ejen langganan akhbarnya. Sebelum itu pada $1887, \mathrm{Hj}$. Muhammad Siraj mengadakan kerjasama dengan penerbit dan peniaga buku yang besar di Pulau Pinang, Hj. Putih Syeikh Abu Basyir untuk mencetak bukubukunya di samping menjadi ejennya. Lihat Ensiklopedia Sejarah dan Kebudayaan 
Melayu, hlm. 1584. Sebagai peniaga buku, Hj. Muhammad Siraj mengeluarkan sebuah katalog yang menyenaraikan 120 penerbitan yang boleh diperoleh di kedainya pada 1897-1898. Lihat Ian Proudfoot, "A Nineteenth-Century Malay Booksellers's Catalogue" dlm. Kekal Abadi 6 (4) Dis 1987, hlm. 1-10. Untuk penglibatan beliau dalam penerbitan dan percetakan pula, lihat Ian Proudfoot, Early Malay Printed Books, Kuala Lumpur: Akademi Pengajian Melayu dan Perpustakaan Universiti Malaya, 1993, hlm. 22-24.

${ }^{24}$ Hamedi Mohd Adnan, Direktori Majalah-majalah Melayu Sebelum Merdeka, Kuala Lumpur: Penerbit Universiti Malaya, 2002, hlm. 45.

${ }^{25}$ Ibid.

${ }^{26}$ Ibid., hlm. 56.

${ }^{27}$ Ibid.

${ }^{28}$ Wihdatul Madaris, Bil. 1, 1 Oktober 1935.

${ }^{29}$ Al-Ikhwan Press muncul buat pertama kalinya sebagai penerbit dan pencetak akhbar Taman Pengetahuan (1 Jun 1904) dan beroperasi di No. 76 \& 77, Arab Street, Kampung Gelam, Singapura. Percetakan ini merupakan milik keluarga di antara Munsyi Muhamad Ali b. Ghulam Al-Hindi dengan Syed Muhamad Abdul Kadir Al-Hindi, dan adiknya Syed Alwee b. Abdul Kadir Al-Hindi. Meskipun Md. Sidin Ishak menyatakan penggerak utamanya Syed Mahmud (?Muhamad), namun berdasarkan rujukan nama percetakan ini sebagai "Alwee Ikhwan tukang cap serba jenis bahasa, penjual jenis 2 kitab sekolah serta kitab Arab, Melayu, Inggeris, perkakas tulis, penjilid kitab2 dan pembuat rubber stamp", kemungkinan besar penggeraknya ialah Syed Alwee. Selain menerbitkan Taman Pengetahuan (terhenti pada 6 Nov 1905), Al-Ikhwan Press turut menerbitkan Penyuloh (30 Mei 1924). Pada tahun 1924 itu dinyatakan bahawa tuan punya Al-Ikhwan Press ialah Syed Zain Alwee Alsagoff. Lihat Penyuloh, 30 Mei 1924. Untuk penglibatan Al-Ikhwan dalam penerbitan buku, lihat Md. Sidin Ahmad Ishak, Penerbitan \& Percetakan Buku Melayu, hlm. 84-85.

${ }^{30}$ Semangat Islam, Bil, 1, 1 November 1929.

${ }^{31}$ Ibid.

32 Seruan Azhar diterbitkan di Kaherah oleh Pemuda-pemuda Melayu Malaya dan Indonesia, dipimpin oleh Djanan Taib. Mujallah Guru, Februari 1928 menyatakan majalah ini sebagai surat khabar bulanan menyeru menuntut pengetahuan kemajuan persatuan dan juga berisi dengan berbagai-bagai perkhabaran yang penting dan karangan-karangan yang meluaskan pemandangan serta gambargambar orang yang masyhur. Pilehan Timur juga diterbitkan di Kaherah, pada Oktober 1927 dan pengarangnya Mokhtar Loutfi. Mujallah Guru, Februari 1928 menyatakannya sebagai "sebuah majalah bahasa Melayu huruf Arab dikeluarkan sebulan sekali dari Mesir. Terhias di dalamnya berbagai-bagai perkara yang berhubung dengan kemajuan dan menambah pengetahuan serta tertib sopan seperti didikan tanah air, jalan mencapai kemajuan, lembaran tarikh, halaman perempuan, tafsir ayat-ayat Quran dan sebagainya. Untuk memperoleh gambaran lebih jelas lihat Ibrahim Hj. Mohd Rashdi, Majallah Seruan Azhar: Bilangan 11-21, dan Abdul Ghani Ishak, Seruan Azhar: Bilangan 22 hingga 32 dirumi dan diedit, kedua-duanya merupakan Latihan Ilmiah Jabatan Sejarah, Universiti Malaya, 1976. 
${ }^{33}$ Lihat Puncha Pertikaian Ulama Islam, November 1929.

${ }^{34}$ Mujallah Al-Kamaliah, 15 Januari 1930.

${ }^{35}$ Abdul Rahman Al-Ahmadi, "Notes Towards a History of Malay Periodicals in Kelantan" dlm. William R. Roff, Kelantan: Religion, Society and Politics in a Malay State, Kuala Lumpur: Oxford Univ. Press, 1974, hlm. 179.

${ }^{36}$ Persama Press yang dimiliki oleh Muhamad Ali b. Muhamad Ar-Rawi sememangnya merupakan antara pencetak Melayu yang utama ketika itu dan telah menjadi sama ada penerbit atau pencetak kepada banyak akhbar dan majalah. Antaranya Puncha Pertikaian Ulama Islam (Nov 1929), Lipuran Duka (23 Ogo 1932, Berita Sekolah (Mac 1934), Persahabatan (21 Jul 1936), Al-Islam (Jul 1936), Suara Kalam (Sep 1936), Lidah Persaudaraan (16 Mac 1937), di samping akhbar Dewasa (19 Okt 1931), Bahtera (1 Jan 1931), Warta Perak (13 Mac 1937). Selain itu, matbaah ini juga mengecap buku, syair, surat jemputan, resit, blok daripada tembaga, rubber stamp, dan sebagainya dengan "...huruf yang dipakai di dalamnya sekalian baru belaka tibanya dari Mesir dan Europe berbaris atau tidak..." (Puncha Pertikaian Ulama Islam, Jun 1930). Pada mulanya Persama Press beroperasi di No. 93, Acheen Street, sebelum dipindahkan ke No. 14 jalan yang sama pada Februari 1937. Selain menjadi pencetak, Persama Press juga menjual buku-buku untuk bacaan umum, sama ada yang diterbitkan di Malaya atau diimport, di samping menjadi pusat pengedaran sebelah utara bagi kebanyakan akhbar dan majalah Melayu.

${ }^{37} \mathrm{Hj}$. Abdul Aziz Syeikh Rahmat merupakan seorang guru agama dan pernah menjadi pengarang atau penerbit akhbar Edaran Zaman (1 Jan 1925) dan Sahabat (15 Feb 1939), majalah Warta Penang (1 Sep 1929) dan Pedoman Islam (19 Apr 1935) di samping pernah menjadi pengarang atau penolong pengarang majalah Chahaya Timur (4 Jan 1930) dan Siasat (15 Okt 1939). Sewaktu beliau menjadi pengarang Sahabat, Abdullah Hussain menyatakan bahawa $\mathrm{Hj}$. Abdul Aziz "hanya datang dua tiga kali seminggu. Orangnya berbadan tegap, memakai kot putih tutup sampai ke leher, bersongkok dan berkain pelikat. Rambutnya sudah putih." Lihat Abdullah Hussain, Sebuah Perjalanan, Kuala Lumpur: Dewan Bahasa dan Pustaka, 1980, hlm. 168.

${ }^{38}$ Pengarang menyatakan: "Berhubung dengan al-Quran dan hadis, maka pada kali yang pertama ini kita hanya dapat menuliskan lafaz, makna, dan sedikit tafsirnya saja, yang kita mengharap mudah-mudahan di masa datang kita dapat mentafsirkan lebih panjang dan sempurna." Pedoman Islam, 19 April 1935.

${ }^{39}$ Pedoman Islam, 19 April 1935.

${ }^{40}$ Al-Islam, Julai 1936.

${ }^{41}$ Mohd Yunus Abdul Hamid merupakan pengarang Indonesia pertama yang memainkan peranan aktif dalam penerbitan beberapa buah majalah dan akhbar Melayu di Pulau Pinang. Beliau berasal dari Langkat dan dilahirkan pada tahun 1889. Pendidikan awalnya bermula di Langkat dan setelah temat persekolahan, Mohd Yunus menjadi kerani pelatih dan kemudian pelatih telegraf di Deli dan seterusnya kerani besar. Pada tahun 1916 beliau meletakkan jawatan dan membuka sebuah syarikat bernama Percetakan Setia Bahasa dan menerbitkan harian Benih Merdeheka bersama-sama seorang peguam, Muhamad Samin. Selepas itu beliau terlibat dalam penerbitan beberapa buah akhbar dan majalah di Betawi dan Deli sebelum Mohd Yunus berhijrah ke Pulau Pinang pada tahun 1924 
bersama-sama rakan karibnya, Syed Taha Al-Sagoff. Di Pulau Pinang beliau diminta Syed Syeikh Al-Hadi membantu mengendalikan majalah Al-Ikhwan meskipun pada tahun itu juga beliau menguruskan Idaran Zaman. Pada tahun 1928 Mohd Yunus menjadi pengarang Saudara yang pertama di samping menguruskan penerbitan Malaya (1926-31), Dewasa (1931-32), dan Persahabatan (1936-37). Pada akhir 1936 beliau kembali ke Indonesia untuk menetap di situ bersama keluarganya. Walau bagaimanapun, anak beliau, Ghazali Yunus melibatkan diri dalam penerbitan pada tahun 1960-an dan 70-an dengan akhbar pendidikannya yang penting, Angkatan Baru. Untuk latar belakang lanjut tentang lihat Mohd Sarim Hj. Mustajab, “Profile Seorang Wartawan 1920an”, hlm. 15966.

${ }^{42}$ Mariah Hj. Salleh, Akhbar Persahabatan 1936-1937: Satu Tinjauan, Latihan Ilmiah Jabatan Sejarah Universiti Kebangsaan Malaysia, 1976/77, hlm. 23.

${ }^{43}$ Persahabatan, 30 Jun 1936. Majalah ini (bilangan pertama) diterbitkan pada 21 Julai 1936 sehingga kemungkinan 27 Januari 1937. Inilah keluaran terakhir yang dapat dikesan setakat ini walaupun dalam keluaran yang terakhir itu, sebelum Persama Press dipindahkan ke No. 14, Acheen Street, pengarang menyatakan "...Persahabatan terpaksa diberhentikan bagi sementara waktu keluarannya. Barangkali buat dua tiga kali bilangannya kemudian akan dikeluarkan sebagai biasa."

${ }^{44}$ Ahmad Press dimiliki oleh Ahmad Abdul Rahman dan beroperasi di Jln Sultan, Singapura sejak 1915. Percetakan ini ditubuhkan di Pulau Tujuh, Singapura dan tujuannya untuk mencapai cita-cita perniagaan di samping untuk melanjutkan aktiviti Matbaah Fataniah di Makkah untuk menjayakan ajaran Islam. Sekurangkurangnya tiga orang daripada keluarga diraja Riau bertanggungjawab menubuhkan percetakan ini, iaitu Raja Ahmad, Raja Hassan, dan Raja Ali. Sebelum itu mereka terlibat dengan Matbaah Ahmadiah di Pulau Penyengat. Lihat Md. Sidin Ahmad Ishak, Penerbitan dan Percetakan Melayu, hlm. 190. Selain menerbitkan majalahnya sendiri, iaitu Dunia Akhirat (25 Jul 1936) dan Kahidupan Dunia Akhirat (17 Sep 1935) matbaah ini turut menawarkan kerja-kerja cetak dalam bahasa Melayu, Arab, Inggeris, "Keling", dan Cina. Di samping itu, Al-Ahmadiah Press (nama yang lebih dikenali selepas dekad 30-an) menjual "... beberapa jenis kitabkitab dan buku-buku Arab, Melayu dan roman serta cerita-cerita dan buku pelajaran budak-budak sekolah, kertas, kad-kad, envelop, perkakas tulis, dan lain-lain." Lihat Dunia Akhirat, 10 November 1936.

${ }^{45}$ Kahidupan Dunia Akhirat, 17 September 1935. Turut dinyatakan bahawa "Nama Kahidupan Dunia Akhirat bersempena dengan sebesar2 dan semustahak2 perkara yang sangat2 dicita dan dihayati oleh sekalian manusia di muka bumi ini. Serta kita sulami lagi dengan hikayat2, pantun2 dan rencana2 yang berfaedah serta gambar2 yang menggirangkan hati bagi menambah kegemaran pembaca2."

${ }^{46}$ Dunia Akhirat, Julai 1936, hlm. 3.

${ }^{47}$ Dunia Akhirat, Bil. 2, Ogos 1936, hlm. 3.

${ }^{48}$ Dunia Akhirat merupakan majalah Melayu pertama yang menggunakan ilustrasi pada cerita-cerita agama dengan gambar-gambar hiasan syurga dan neraka.

${ }^{49}$ Royal Press ditubuhkan pada 1920 di Surabaya, Indonesia dan dimiliki oleh Ali. Pada peringkat awal, Royal Press hanya mencetak label atau pelekat botol sejenis minuman, Lamonade. Pencetak ini mengalami kesulitan modal dan pada 1925, 
Ali berpindah ke Singapura dan menubuhkan syarikat baru, Regal Press di Haji Lane. Regal Press meneruskan kerja-kerja percetakan label botol Lamonade di samping upah mencetak kecil-kecilan. Pada 1927, ia mencetak majalah Temasek. Setelah empat keluaran, Regal Press berpindah ke North Bridge Road dan diubah nama kepada Syarikat Royal Press Ltd yang kemudiannya mencetak majalah Medan Laki-Laki. Daripada situ, Royal Press berkembang menjadi salah sebuah pencetak Melayu yang utama di Singapura dan pada 1950-an, perniagaan itu diuruskan oleh anaknya, $\mathrm{Hj}$. Abu Talib Ali. Lihat Abu Talib Ali, "Tugas percetakan kita", Hiburan Sepuluh Tahun, 1956, hlm. 119.

${ }^{50}$ Medan Laki-Laki, 27 September 1935.

${ }^{53}$ Ibid., hlm. 3.

${ }^{52}$ Hamedi Mohd Adnan, "Ekonomi penerbitan majalah Melayu sebelum merdeka", Disertasi PhD, Jabatan Pengajian Media, Universiti Malaya, 2001, hlm. 351. 